\title{
Calcium, snails, and birds: a case study
}

\author{
Raivo Mänd, Vallo Tilgar and Agu Leivits
}

Mänd, R., Tilgar, V. and Leivits, A. 2000. Calcium, snails, and birds: a case study. - Web Ecol. 1: 63-69.

\begin{abstract}
Recent studies have shown that wild birds breeding in acidified areas have difficulties with obtaining sufficient calcium for their eggshells, and that the cause of it is the shortage of land snails. Many birds have to search for Ca-rich snail shells on a daily basis during egg production. Molluscs depend on litter calcium, which has decreased due to acidification of the environment. Calcium limitation may be a widespread phenomenon also in non-acidified, naturally Ca-poor areas. The problem is that while in the latter areas the time for development of specific adaptations may have been sufficient, then in acidified areas, on the contrary, calcium shortage is a recent phenomenon. Therefore, since the extent of calcium limitation in non-acidified areas is hard to derive from observational data, experimental approach is needed. We provide experimental evidence that specific calcium deficit does affect reproductive traits also in the birds breeding in naturally base-poor habitats. Our study was conducted in a heterogeneous woodland area in Estonia containing deciduous forest patches as well as base-poor pine forest with low snail abundance. Ca supplementation, using snail shell and chicken eggshell fragments, was carried out for pied flycatchers and great tits. Extra calcium affected positively several reproductive traits like egg volume and eggshell thickness, start of breeding, and fledglings' parameters. The negative relationship between calcium availability and lay-date suggests that birds adjust their breeding tactics to conditions of Ca deficiency, for example, by postponing laying.
\end{abstract}

R. Mänd (raivo.mand@ut.ee) and V. Tilgar, Dept of Zoology and Hydrobiology, Univ. of Tartu, Vanemuise 46, Tartu 51014, Estonia. - A. Leivits, Nigula Nature Reserve, Pärnu St. 2, Kilingi-Nõmme 86303, Estonia.

The importance of calcium for living organisms is a wellknown fact. It is widely understood that some animals, like crustaceans, molluscs and birds, require calcium in unusual quantities during certain stages of their life. For example, egg-laying birds need $10-15$ times as much calcium per day as reptiles and mammals with developing eggs or embryos (Simkiss 1967). The reason is that ca 95\% of eggshell's dry weight is calcium carbonate. Due to high calcium demand and a restricted ability to store this element in the skeleton, most insectivorous and granivorous birds must collect calcium on a daily basis (Graveland and van Gijzen 1994, Perrins 1996, Reynolds 1997, Graveland and
Berends 1997, Pahl et al. 1997). At the same time the calcium content of their normal food is usually insufficient for shell formation (Graveland and van Gijzen 1994). Several observations show that some birds collect additional calcium-rich material, like snail shells or calcareous grit, during egg-laying (see Perrins 1996 for examples).

Despite all these facts, the subject itself has remained poorly studied, and the position of calcium availability among the ecological factors affecting avian breeding performance has been underestimated. However, the subject has been highlighted in recent years, particularly by Graveland and his colleagues (Graveland 1990, 1996a, b, Grave- 
land and van Gijzen 1994, Graveland et al. 1994, Graveland and van der Wal 1996, Graveland and Berends 1997, Graveland and Drent 1997). They paid attention to several observations that certain species of birds appeared to have trouble acquiring sufficient calcium for their eggs in some heavily acidified regions (Drent and Woldendorp 1989, Graveland 1990). They showed experimentally that defective eggshells in great tits in the Netherlands were related to decline in snail abundance in acidified soils. Snail shells are claimed to be the main calcium source for eggshell formation in many forest bird species (Schifferli 1973, Graveland et al. 1994, Perrins 1996). Molluscs need calcium for their calcareous shells, but continuing acidification and base cation leaching may lead to decreased calcium content in litter and the surface soil layer (Wäreborn 1969, 1970, 1992). Indeed, a remarkable decline in land snail populations has recently been revealed not only in the Netherlands (Graveland et al. 1994, Graveland and van der Wal 1996) but also in southern Sweden (Wäreborn 1992, Gärdenfors et al. 1995).

Graveland and Drent (1997) have hypothesised that calcium limitation may, in fact, occur not only in acidified areas but also in non-acidified, calcium-poor areas. There are large regions in the world with acidic rock or soils where snail shells or other calcium sources are scarce. As Graveland and Berends (1997) have demonstrated, obtaining sufficient calcium is time-consuming even in calcium-rich environments. Therefore the real cost of egg formation in base-poor areas might be much higher than has been estimated on the basis of the energy and protein content of eggs. However, in naturally base-poor areas the time for development of specific adaptations may have been sufficient, in contrast to acidified areas where calcium shortage is a recent phenomenon (Graveland and Drent 1997). Certain adaptations may have developed in parallel to adaptations to low availability of other nutrients. Consequently, since the extent of calcium limitation in non-acidified areas cannot be derived from observational data, an experimental approach is needed.

Industrial acidification does not yet pose a grave problem in Estonia (Frey 1988, Sepp and Asi 1994). At the same time, a substantial part of the country's territory is covered with pine forests on poor, naturally acidic soils (Taimre 1989). Due to the rather low density of human population, calcium deficiency in such habitats cannot be compensated for as easily as in the Netherlands by using anthropogenic calcium sources (Graveland 1996a, Graveland and Drent 1997).

In 1995-1997 and 1999, we carried out a series of calcium-supplementation experiments in great tits Parus major L. and pied flycatchers Ficedula hypoleuca Pall. in SW Estonia. Simultaneously, we collected data on the abundance of land snails in our study area as well as in other forests all over the country. In this paper we 1) show that the density of snails in many Estonian forests is low, and 2) provide experimental evidence that birds in such forests do suffer specific calcium shortage.

\section{Material and methods}

\section{Study area}

Our study was conducted in a heterogeneous woodland area in southwestern Estonia $\left(58^{\circ} 7^{\prime} \mathrm{N}, 25^{\circ} 5^{\prime} \mathrm{E}\right)$ containing deciduous forest patches as well as coniferous forests. The area is situated in the transition zone from a base-rich moraine plateau to base-poor sand dunes. In deciduous forests, Alnus incana (L.) Moench and Betula pendula Roth were the predominant tree species, and there was a rich understorey. In coniferous forests, the dominant tree species was Pinus sylvestris $\mathrm{L}$., which sometimes formed mixed stands with Picea abies (L.) H. Karst (on sandy soil) and Betula pubescens Ehrh (on peat soil). In the field layer, the dwarf shrubs Vaccinium myrtillus L. and Vaccinium vitisidaea L. were the most prevalent species. Our study plots contained nest-box lines and were distributed over an area of ca $50 \mathrm{~km}^{2}$.

\section{Bird study}

Wooden board nest-boxes with an entrance of $3.5-4.0 \mathrm{~cm}$ in diameter and a nest cavity with approximate dimensions $11 \times 11 \times 30 \mathrm{~cm}$ were mounted on tree trunks $1.5-2 \mathrm{~m}$ above ground level. The distance between neighboring boxes was ca $50 \mathrm{~m}$. Old nest material was removed each year. The boxes were checked regularly to record: 1) date of the first egg, 2) clutch size, 3) hatching success and 4) number of fledged young. Only first clutches were taken into account. Depredated or deserted nests were omitted when calculating fledging success. In 1995-1996, one egg from each clutch (with an exception of 2 eggs in great tit in 1995) was collected randomly to measure the thickness of the eggshell. In the pied flycatcher, the egg was removed on the 3rd or 4th day after the start of laying and, in the great tit, on the 6th (1) day of incubation. The eggs were photographed. A graphics digitizer was used for the input of egg contours from photographs, and egg volume was estimated using the method described in Mänd et al. (1986). In 1996, whole clutches of the great tit were photographed in the field, and mean egg volume per clutch was used in analysis (see Hórak et al. 1997 for more details). The collected eggs were cut into halves using a razor-blade, their content was removed and the eggshell carefully washed. The eggshells were dried in a desiccator and shell thickness was measured using a digital micrometer. The mean of three measurements from the equatorial zone of an egg was used in analysis. Nestlings were weighed with a Pesola spring balance, and their tarsi were measured with a sliding caliper on the 13th day (pied flycatcher) and 15th day (great tit) after hatching. Adults were captured during the second half of the nestling period, and their age and sex were determined from plumage characteristics (Svensson 1984). They were also weighed, and their tarsal and wing lengths were measured. 
Calcium supplementation was carried out in pine forests in 1995-1997 and both in pine and deciduous forests in 1999. In 1995, part of the great tits nesting in the deciduous habitat were also fed with extra calcium. Feeders filled with small snail shell and chicken egg shell fragments were mounted on nest-boxes. The feeders were regularly checked and refilled, so that there was always a surplus of calcium-rich material. We also attached empty feeders to control nest-boxes to check for the possible influence of the feeders per se on breeding results. Experimental and control nest-boxes were arranged in separate five-box blocks. Since there existed a certain probability that filled feeders were used also by birds from adjacent nest-boxes without calcium (Graveland and Drent 1997), control nest-boxes next to experimental boxes were omitted from analysis. The distance between control and experimental blocks was at least $100 \mathrm{~m}$ (see methods in Graveland and Drent 1997). As a rule, no more than one nest-box per block was occupied by either species.

\section{Snail study}

In 1995, a quantitative study of land snails was carried out in a number of forests all over Estonia (Mänd et al. 1997). Ten litter samples were collected from each study plot us- ing $25 \times 25 \mathrm{~cm}$ square quadrates with a distance of $10 \mathrm{~m}$ from each other. All samples were collected in dry weather during a short mid-summer period between 22 July and 8 August. The samples contained herbs, lichens, mosses and the litter layer plus the top $1-2 \mathrm{~cm}$ of the mineral soil. The material was air-dried and carefully hand-sorted by experienced snail specialists in laboratory conditions, using a magnifying glass. Searching time per sample was $0.5-1.5 \mathrm{~h}$ depending on sample volume. All snails (alive individuals and empty shells separately) were counted and identified, and their maximum diameter was measured.

In 1995 and 1999, we counted snails also in the area of our calcium-supplementation experiments. Ten litter samples were taken from random sites in pine forests and ten samples from deciduous forests. The samples were collected on 20 May in 1995 and 3 May in 1999.

\section{Results}

\section{Snails}

Available data on snail density in several Estonian deciduous and pine forests are summarized in Table 1 (together with data from the Netherlands). As expected, more snails live in deciduous than in pine forests. Hundreds of snail

Table 1. Density of land snails (alive + empty shells) in the forests of the Netherlands and Estonia.

\begin{tabular}{|c|c|c|c|c|c|}
\hline Country & Description of the forest & Year & Season & Snail shells $\mathrm{m}^{-2}$ & Source \\
\hline & \multicolumn{5}{|l|}{ Forests on nutrient-rich soils } \\
\hline Netherlands & $\begin{array}{l}\text { Three ash forests on nutrient-rich } \\
\text { clay or loam soils }\end{array}$ & 1973 & September & $35-304$ & \multirow{3}{*}{$\begin{array}{l}\text { Graveland and } \\
\text { van der Wal } 1996 \\
\text { “ } \\
\text { “ }\end{array}$} \\
\hline “ & Same forests & 1992 & “ & $72-206$ & \\
\hline “ & $\begin{array}{l}\text { Four oak forests on nutrient-rich } \\
\text { clay or loam soils }\end{array}$ & 1992 & $\begin{array}{l}\text { Late April - } \\
\text { early June }\end{array}$ & $58-1581$ & \\
\hline Estonia & $\begin{array}{l}\text { Three deciduous/mixed forests on } \\
\text { nutrient-rich soils, W Estonia }\end{array}$ & 1995 & $\begin{array}{l}\text { Late July - } \\
\text { early August }\end{array}$ & $146-427$ & Mänd et al. 1997 \\
\hline “ & $\begin{array}{l}\text { Three deciduous/mixed forests on } \\
\text { nutrient-rich loam soils, S Estonia }\end{array}$ & 1995 & $\begin{array}{l}\text { Late July - } \\
\text { early August }\end{array}$ & $69-219$ & “ \\
\hline \multirow[t]{2}{*}{ “ } & $\begin{array}{l}\text { Deciduous forest on nutrient-rich } \\
\text { loam soil, SW Estonia }\end{array}$ & $\begin{array}{l}1995, \\
1999\end{array}$ & May & $92-214$ & $\begin{array}{l}\text { Tilgar et al. 1999, } \\
\text { this study }\end{array}$ \\
\hline & Forests on nutrient-poor soils & & & & \\
\hline Netherlands & $\begin{array}{l}\text { Two pine forests on nutrient-poor } \\
\text { sand soils }\end{array}$ & 1970 & November & $34-81$ & \multirow{3}{*}{$\begin{array}{l}\text { Graveland and } \\
\text { van der Wal } 1996 \\
\text { “ } \\
\text { “ }\end{array}$} \\
\hline “ & Same forests & 1992 & “ & $7-39$ & \\
\hline “ & $\begin{array}{l}\text { Ten mixed coniferous-deciduous } \\
\text { forests on nutrient-poor sand soils }\end{array}$ & 1992 & $\begin{array}{l}\text { Late April - } \\
\text { early June }\end{array}$ & $0-826$ & \\
\hline Estonia & $\begin{array}{l}\text { Three pine forests on nutrient-poor } \\
\text { sand soils, W Estonia }\end{array}$ & 1995 & $\begin{array}{l}\text { Late July - } \\
\text { early August }\end{array}$ & $10-48$ & Mänd et al. 1997 \\
\hline “ & $\begin{array}{l}\text { Three pine forests on nutrient-poor } \\
\text { sand soils, S Estonia }\end{array}$ & 1995 & $\begin{array}{l}\text { Late July - } \\
\text { early August }\end{array}$ & $0-2$ & “ \\
\hline “ & $\begin{array}{l}\text { Pine forest on poor sand or peat } \\
\text { soils, SW Estonia }\end{array}$ & $\begin{array}{l}1995, \\
1999\end{array}$ & May & $\begin{array}{l}13-75 \\
\text { this study }\end{array}$ & Tilgar et al. 1999, \\
\hline
\end{tabular}


shells can be counted from a square metre in deciduous forests, while in pine forests the density of snails does not exceed some tens of individuals per square metre. There exists also remarkable contrast between western Estonia (situated on Silurian limestone bedrock) and southern Estonia (Devonian sandstone bedrock) within each type of forest. Extremely few snails were found in extensive homogeneous pine forests of S. Estonia where most litter samples did not contain snail shells at all.

Table 2 presents data on snail abundance and species richness in the two contrasting habitats of our experimental area during the breeding season of 1999 . The density of snails in the deciduous habitat was more than two times and the species richness four times higher than in pine forests. As regards to a possible calcium source for egg-laying birds, the mass of the snail shells per unit surface area would have served as the best indicator. Regrettably, we did not weigh the shells. Still, "shell index" in the last row of the table yields a rough estimate of this parameter. Since it is more than five times larger in deciduous than in coniferous forests, it means that not only the density is lower but also the average size of snails is smaller in the latter habitat.

\section{Birds}

Both visual observations and analysis of nest material confirmed that birds had consumed snail shell and egg shell fragments in the feeders. Chicken eggshell fragments were found mostly in the Ca-supplemented nests of the great tit and only in the Ca-supplemented nests of the pied flycatcher.

Ca-fed females of the great tit tended to start egg-laying earlier than did control birds in three of four years studied (Table 3). There exists a significant positive relationship between annual median laying date and advancement of laying in Ca-fed pairs (Fig. 1, $\mathrm{R}^{2}=0.37, \mathrm{~F}_{1,77}=46.1, \mathrm{p}<$ 0.001 ). When data for the year 1999 (the earliest start of laying) was omitted from analysis, the effect of calcium supplementation on lay-date became significant $(\mathrm{p}<$ 0.01 ). In the pied flycatcher, there was no effect of extra calcium on laying date in any but one year, 1999. This was the year with the latest start of breeding in flycatchers. In the same year Ca-fed females of the pied flycatcher tended to start egg-laying earlier than did control birds both in the coniferous and deciduous habitats, although the difference was significant only for pine forest (coniferous habitat: $Z_{82,73}=-2.42, p=0.016$; deciduous habitat: $Z_{38,40}=-1.0, p$ $=0.32$ ).

Data on egg volume are available for the years 19951997 and on eggshell thickness for 1995-1996. In the pied flycatcher, both these parameters tended to have higher values in Ca-fed females than in the control group in all the years studied (Table 4, egg volume: $p<0.01$; eggshell thickness: $p<0.001)$. In the great tit we observed no significant effect of calcium supplementation on egg parameters, although the mean egg volume of Ca-fed females was slightly larger than in control birds in 1996-1997, the two years with the latest start of breeding. There was also a significant positive effect of extra calcium on clutch volume (sum of the volumes of all laid eggs) in the great tit.

We detected no regular effect of calcium supplementation on the clutch size and production of fledglings when data were pooled over years. However, in the pied flycatcher, clutch size in Ca-fed females was slightly larger than in controls both in the deciduous ( 6.9 vs 6.6 eggs) and coniferous habitats (6.8 vs 6.6 eggs) in 1999, the year with the latest start of breeding. The difference became significant only when data were pooled over habitats ( $\mathrm{t}$-test, $\mathrm{t}_{121,106}=$ $2.18, p=0.03$, square root transformation of data).

In the pied flycatchers breeding in the coniferous habitat, the tarsus of fledglings was longer in Ca-fed than in control nests $\left(\mathrm{F}_{1,158}=4.6, \mathrm{p}=0.03\right)$. Tarsus length and body weight of great tit fledglings in Ca-fed nests were significantly larger than in controls only in 1997, the year with the latest start of breeding, when the results were controlled for hatching date (tarsus: $\mathrm{p}<0.05$, body weight: $\mathrm{p}=$ 0.05).

Table 2. Abundance* and species richness of land snails in different habitats of the study area in May 1999.

\begin{tabular}{lcrrrl}
\hline & \multicolumn{2}{c}{ Pine forest $\mathrm{n}=10$} & \multicolumn{2}{c}{ Deciduous $\mathrm{n}=10$} & \multirow{2}{*}{$\mathrm{p}^{* *}$} \\
& Mean & SD & Mean & SD & \\
\hline Alive individuals & 2.6 & 4.7 & 6.7 & 6.3 & 0.019 \\
Alive + empty shells & 4.7 & 8.0 & 13.4 & 12.3 & 0.019 \\
Number of species & 1.4 & 1.8 & 5.8 & 3.2 & 0.002 \\
Shell index*** & 10.2 & 16.6 & 52.3 & 50.2 & 0.012 \\
\hline
\end{tabular}

* all means are calculated per $25 \times 25 \mathrm{~cm}$ litter sample

** Mann-Whitney U-test

*** calculated as the sum of the maximum diameters of all snail shells (alive + empty) per $25 \times 25 \mathrm{~cm}$ litter sample 
Table 3. Start of egg-laying in Ca-fed and control groups of great tits in the coniferous habitat.

\begin{tabular}{lcccccc}
\hline Year & Median & $\begin{array}{c}\text { Ca-fed } \\
\text { Quartile range }\end{array}$ & $\mathrm{N}$ & Median & $\begin{array}{c}\text { Control } \\
\text { Quartile range }\end{array}$ \\
\hline 1995 & 27 & 4 & 13 & 29 & 6 & 50 \\
1996 & 34 & 2 & 16 & 35.5 & 4 & 22 \\
1997 & 36 & 4 & 13 & 40.5 & 6.5 & 12 \\
1999 & 26 & 3 & 37 & 25 & 3 & 37 \\
\hline
\end{tabular}

Note. Laying time is given in days from 1 April (e.g., median time 34 in the table means 4 May). Mann-Whitney U test for pooled data: $\mathrm{p}=0.082$. When data for the year 1999 (the earliest start of laying) was omitted from analysis, the effect of calcium became significant $(\mathrm{p}<0.01)$.

\section{Discussion}

\section{Snails}

Comparison of snail abundance in different geographical or ecological regions is often problematic, since different investigators have used different methods, and snail samples have been collected in different periods of the year. We used the same method as Graveland and colleagues (Graveland and van der Wal 1996), while both they and we collected part of the material in spring. There exists no large difference in snail numbers between forests in the acidified area of the Netherlands and the non-acidified area of Estonia. In pine forests of southern Estonia, situated on the Devonian sandstone bedrock, the density of snails is extremely low. Data for snails from our main study area in 1999 as well as the results of an earlier study (Tilgar et al. 1999) suggest that there is a clear contrast in snail abundance between our deciduous and coniferous breeding habitats.

Pine forests on poor, naturally acidic soil constitute a substantial part (ca 16\%) of Estonia's territory ( $40 \%$ of all woodlands) (Taimre 1989). Thus, if snail abundance is in- deed a reliable indicator of calcium accessibility for birds in their breeding habitats, then passerines in many base-poor forests of Estonia might probably face similar problems as their conspecifics in acidified areas.

\section{Birds}

The results of our experiments support the above assumption. Both studied passerine species consumed the calcium-rich material in the feeders. Several breeding parameters revealed regularly better values in $\mathrm{Ca}$-fed females than in controls, and no one parameter behaved the other way round. It is noteworthy that the effect of extra calcium seemed to be the more pronounced, the later occurred the start of breeding in that particular year. Some differences proved to be significant only in the years with the latest breeding, or when data for the year with the earliest start of egg-laying was excluded from analysis. Late start of egglaying in birds usually correlates with unfavourable weather conditions during the pre-breeding period (Lundberg and Alatalo 1992, Nager and van Noordwijk 1995), which limits the supply of energy and nutrients
Fig. 1. Laying advancement in Ca-fed great tits in relation to median laying date in control pairs in 1995-1997 and 1999. Rectangles denote SE and vertical lines $95 \%$ confidence intervals. Numbers are sample sizes.

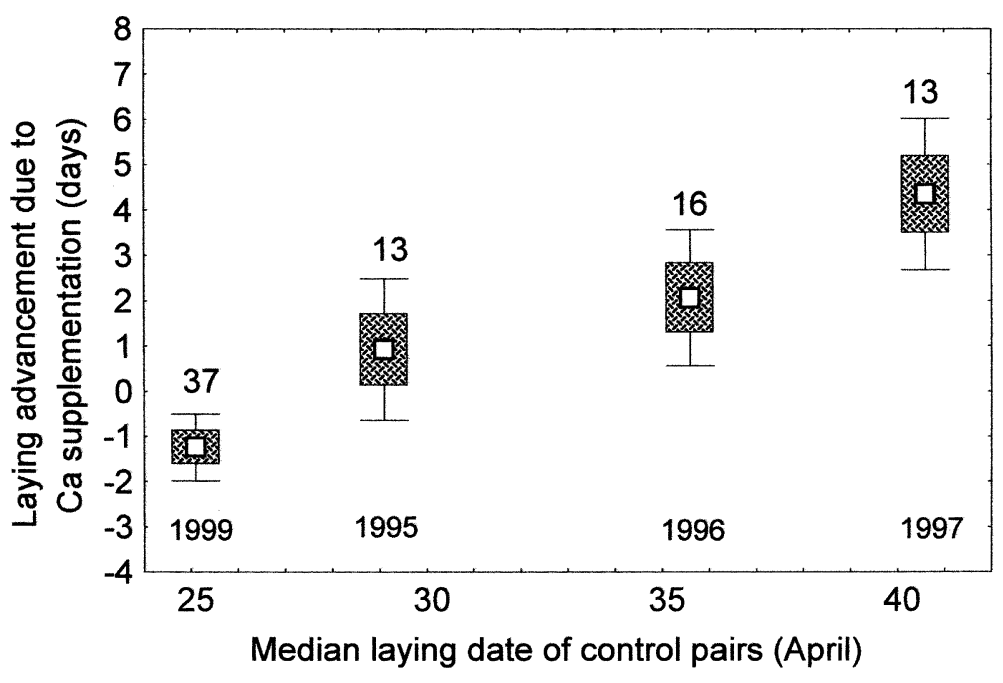


Table 4. Egg volume and eggshell thickness in Ca-fed and control groups of the pied flycatcher in the coniferous habitat. After Tilgar et al. 1999 .

\begin{tabular}{|c|c|c|c|c|c|c|c|}
\hline \multirow[t]{2}{*}{ Egg parameter } & \multirow[t]{2}{*}{ Year } & \multicolumn{3}{|c|}{ Ca-fed } & \multicolumn{3}{|c|}{ Control } \\
\hline & & Mean & SD & $\mathrm{N}$ & Mean & SD & $\mathrm{N}$ \\
\hline \multirow[t]{3}{*}{ Volume $\left(\mathrm{cm}^{3}\right)$} & 1995 & 1.68 & 0.12 & 19 & 1.61 & 0.15 & 48 \\
\hline & 1996 & 1.58 & 0.10 & 32 & 1.53 & 0.11 & 34 \\
\hline & 1997 & 1.60 & 0.15 & 57 & 1.57 & 0.12 & 52 \\
\hline \multirow[t]{2}{*}{ Shell thickness $(\mu \mathrm{m})$} & 1995 & 83.2 & 4.5 & 19 & 78.5 & 5.3 & 51 \\
\hline & 1996 & 76.5 & 5.4 & 34 & 73.5 & 7.7 & 33 \\
\hline
\end{tabular}

ANOVA; the effect of calcium on egg volume: $\mathrm{p}<0.01$, on eggshell thickness: $\mathrm{p}<0.001$; the effect of year on both characters was highly significant.

needed by the female for egg production (Perrins 1970, 1996). Indeed, the latest breeding year in the great tit was 1997, when the spring was cold and the snow stood unusually long. Similarly, the latest breeding in the pied flycatcher was in 1999, when an extremely severe cold wave, accompanied with a snowstorm, befell the country in midMay, just prior to the normal time of egg-laying for this species. It seems, therefore, that food shortage during a particularly harsh breeding season amplifies the negative effect of calcium deficiency. This can be explained by a trade-off between feeding time and the time spent on calcium searching (Graveland and Berends 1997, Graveland and Drent 1997). The same trade-off may also help to understand why calcium supplementation affected not only eggshell thickness and fledglings' tarsus, but also other traits, revealing no direct relationship with calcium availability.

Note that the results of our experiments in a particular year often differed for the two bird species. The reason of this is that the time interval between the median laying dates of the two species is quite long. Due to unstable climatic conditions in our study area, it may happen that one and the same year is very favourable for tits but very unfavourable for flycatchers, or vice versa. Moreover, even for one species, conditions in a particular year may be unfavourable during egg-laying but favourable during the nestling period (as was the case with, e.g. flycatchers in 1999).

Regrettably, most of our experiments were carried out only in the coniferous habitat. Therefore we do not know if calcium deficiency is a more limiting factor for birds in the coniferous than in the deciduous habitat. However, our finding that the effects of calcium supplementation on laying date and clutch size of the pied flycatcher coincided in both habitats in 1999, suggests that flycatchers suffer calcium shortage also in our relatively snail-rich deciduous forests, at least in the most unfavourable years.

Our results also supported the assumption that birds in naturally base-poor regions may have been adaptated to calcium shortage (Graveland and Drent 1997). We detected positive effects of extra calcium on the onset of laying in all but the earliest breeding season in case of the great tit and the most unfavourable season in case of the pied flycatcher. Advancement of laying in the great tit was positively correlated with the annual median laying date. These findings suggest that birds postpone breeding in conditions where low calcium availability is accompanied with scanty food supply. However, we found no evidence that production of fledglings in such birds was lower than in calcium-fed birds.

Acknowledgements - The study was supported by Estonian Science Foundation grants No. 1631, 2217 and 3905. We are grateful to Annelie Ehlvest, Tiina Talvi and Piret Kiristaja for analysis of snail samples.

\section{References}

Drent, P. J. and Woldendrop, J. W. 1989. Acid rain and eggshells. - Nature 339: 431.

Frey, T. 1988. Acid rains in Estonia. - Eesti Loodus (Estonian Nature) 31: 1-8, 10-12, in Estonian.

Gärdenfors, U., Waldén, H. W. and Wäreborn, I. 1995. Effects of soil acidification on forest land snails. - Ecol. Bull. 44: 259-270.

Graveland, J. 1990. Effects of acid precipitation on reproduction in birds. - Experientia 46: 962-970.

Graveland, J. 1996a. Avian eggshell formation in calcium-rich and calcium-poor habitats: importance of snail shells and anthropogenic calcium sources. - Can. J. Zool. 74: 10351044.

Graveland, J. 1996b. Eggshell defects in forest passerines caused by decline of snail abundance on acidified soils. - Vogelwelt 117: 67-73.

Graveland, J. and van Gijzen, T. 1994. Arthropods and seeds are not sufficient as calcium sources for shell formation and skeletal growth in passerines. - Ardea 82: 299-314.

Graveland, J. and van der Wal, R. 1996. Decline in snail abundance due to soil acidification causes eggshell defects in forest passerines. - Oecologia 105: 351-360.

Graveland, J. and Berends, A. E. 1997. Timing of the calcium uptake and effect of calcium deficiency on behaviour and egg-laying in captive great tits, Parus major. - Physiol. Zool. 70: $74-84$. 
Graveland, J. and Drent, R. H. 1997. Calcium availability limits breeding success of passerines on poor soils. $-\mathrm{J}$. Anim. Ecol. 66: 279-288.

Graveland, J. et al. 1994. Poor reproduction in forest passerines from decline of snail abundance on acidified soils. - Nature 368: 446-448.

Hórak, P., Mänd, R. and Ots, I. 1997. Identifying targets of selection: a multivariate analysis of reproductive traits in the great tit. - Oikos 78: 592-600.

Lundberg, A. and Alatalo, R. V. 1992. The pied flycatcher. Poyser.

Mänd, R., Nigul, A. and Sein, E. 1986. Oomorphology: a new method. - Auk 103: 613-617.

Mänd, R. et al. 1997. Tigude arvukus ja liigirikkus Eesti metsades (Numbers and species richness of snails in Estonian forests). - In: Frey, T. (ed.), Kaasaegse ökoloogia probleemid: ajalised muutused Eesti eluslooduses ja keskkonnas (Problems of contemporary ecology: temporal changes in Estonian nature and environment). Short communications of Estonian VII conference in ecology. Estonian Council of Ecology, pp. 143-148, in Estonian.

Nager, R. G. and van Noordwijk, A. J. 1995. Proximate and ultimate aspects of phenotypic plasticity in timing of great tit breeding in a heterogeneous environment. - Am. Nat. 146: 455-474.

Pahl, R. et al. 1997. Songbirds do not create long-term stores of calcium in their legs prior to laying: results from high-resolution radiography. - Proc. R. Soc. Lond. B 264: 239-244.

Perrins, C. M. 1970. The timing of birds' breeding season. - Ibis 112: 245-255.

Perrins, C. M. 1996. Eggs, egg formation and the timing of breeding. - Ibis 138: 2-15.
Reynolds, S. J. 1997. Uptake of ingested calcium during egg production in the zebra finch (Taeniopygia guttata). - Auk 114: 562-569.

Schifferli, L. 1973. The effect of egg weight on the subsequent growth of nestling great tits Parus major. - Ibis 115: 549558.

Sepp, R. and Asi, E. 1994. Monitoring of forest soils: aims and preliminary results. - In: Frey, T. (ed.), Kaasaegse ökoloogia probleemid: alalhoidlik areng ja looduskeskne elulaad (Problems of current ecology: sustainable development and natural way of life). Proc. of the 6th Estonian Ecol. Conf. Tartu, pp. 125-128, in Estonian.

Simkiss, K. 1967. Calcium in reproductive physiology. - Chapman and Hall.

Svensson, L. 1984. Identification guide to European passerines. 3rd ed. - Naturhistoriska Riksmuseet, Stockholm.

Taimre, H. 1989. Fundamentals of forest management. - Valgus, Tallinn, in Estonian.

Tilgar, V., Mänd, R. and Leivits, A. 1999. Effect of calcium availability and habitat quality on reproduction in pied flycatcher Ficedula hypoleuca and great tit Parus major. - J. Avian Biol. 30: 383-391.

Wäreborn, I. 1969. Land molluscs and their environments in an oligotrophic area in southern Sweden. - Oikos 20: 461-479.

Wäreborn, I. 1970. Environmental factors influencing the distribution of land molluscs of an oligotrophic area in southern Sweden. - Oikos 21: 286-291.

Wäreborn, I. 1992. Changes in the land mollusc fauna and soil chemistry in an inland district in southern Sweden. - Ecography 15 : 62-69. 